American Journal of Environmental Sciences 5 (6): 678-687, 2009

ISSN 1553-345X

(C) 2009 Science Publications

\title{
Heavy Metals Analysis and Sediment Quality Values in Urban Lakes
}

\author{
Aboud S. Jumbe and N. Nandini \\ Department of Environmental Science, Bangalore University, \\ Jnanabharathi Campus, Bangalore 560056, India
}

\begin{abstract}
Problem statement: The objective of this research was to evaluate the degree of heavy metal contamination in lakes and the extent to which the sediment quality of the lakes of Bangalore city has deteriorated. Approach: In this study, heavy metals such as $\mathrm{Cd}, \mathrm{Co}, \mathrm{Cu}, \mathrm{Cr}, \mathrm{Mn}, \mathrm{Pb}, \mathrm{Ni}$ and $\mathrm{Zn}$ in lake bed sediments were analyzed using comparative sediment quality guidelines from various derived criteria. The selection of sampling points was based upon inflow and outflow regions of the lakes; geographical proximity of industrial units in relation to their effluent discharges; proximity of residential sites located on the banks of the wetland systems; drainage patterns and accessibility towards the lakes. Digestion and analysis of the samples were done by microwave-assisted digestion and atomic absorption spectrophotometry respectively. Results: The extent of sediment quality deterioration was more pronounced in $\mathrm{Cu}(203.50 \mathrm{ppm})$ and $\mathrm{Ni}(97.64 \mathrm{ppm})$ followed by $\mathrm{Pb}$ $(206.0 \mathrm{ppm})$ and $\mathrm{Cd}(8.38 \mathrm{ppm}) . \mathrm{Cr}(96.70 \mathrm{ppm})$ failed a single sediment quality guideline while $\mathrm{Zn}$ (220.0 ppm), Mn (176.0 ppm) and Co (47.7 ppm) remained within the safety levels of sediment quality guidelines prescribed for the study. The Sediment Geo-accumulation Index showed that $\mathrm{Co}, \mathrm{Cu}$ and $\mathrm{Pb}$ showed moderate levels of pollution while the Pollution Load Index (PLI) between heavy metals in the lakes produced the following outputs: $\mathrm{Ni}>\mathrm{Pb}>\mathrm{Cd}>\mathrm{Cu}>\mathrm{Cr}>\mathrm{Co}>\mathrm{Zn}>\mathrm{Mn}$. Conclusion: This study proves that the level of sustained metal contamination of the fragile urban wetlands has not receded even after the recent urban wetlands rejuvenation works were completed. This prolonged presence in excessive levels of the studied heavy metals in the bed sediments casts doubt on the choice and effectiveness of the any mitigation measures in the long run.
\end{abstract}

Key words: Sediment quality guidelines, microwave digestion, atomic absorption spectrophotometry

\section{INTRODUCTION}

The problems associated with heavy metals in waste and storm water drainage entering the natural urban aquatic ecosystems have been well documented and studied. Heavy metals are widespread pollutants of great environmental concern as they are nondegradable, toxic and persistent with serious ecological ramifications on aquatic ecology ${ }^{[1-3]}$. Humans have always depended on aquatic resources for food, medicines and materials as well as recreational and commercial purposes such as fishing and tourism ${ }^{[4]}$. In addition, aquatic ecosystems have significant impact on migratory bird species that use the water bodies as sanctuary and stop-over for food, breeding and nesting. The urban aquatic ecosystems are strongly influenced by long term discharge of untreated domestic and industrial wastewaters, storm water runoff, accidental spills and direct solid waste dumping ${ }^{[5]}$. All these released pollutants have a great ecological impact on the water quality and its surrounding food web ${ }^{[6,7]}$,

Sediments are integral and inseparable parts of the aquatic environments because they help to determine the overall assessment of heavy metals in water vis-avis aquatic life and survivability ${ }^{[8]}$. Since sediments play a very important role in physicochemical and ecological dynamics, any change in toxic concentrations of heavy metal residues on the sediments will affect the natural aquatic life support systems. Locally, not enough studies have been documented in details on the fate of lake bed sediments in the study area. However, Lokeshwari and Chandrappa ${ }^{[9,10]}$ have characterized in details the fate of soil and sediment contamination in other lakes of the study area. Assuming background values of a rejuvenated lake as bench mark for uncontaminated sediments, these studies were able to also derive the sediment geo-accumulation index in these lakes in order to determine the scale of

Corresponding Author: Aboud S. Jumbe, Department of Environmental Science, Bangalore University, Jnanabharathi Campus, Bangalore 560056, India Tel: +918022961367 
contamination of a chemical species involved using case studies on selected lakes.

The overall objective of this research work was to evaluate the degree and extent to which the heavy metal contamination has affected the lakes inside the urban perimeters of Bangalore. In this study, heavy metals such as Cadmium $(\mathrm{Cd})$, Cobalt $(\mathrm{Co})$, Copper $(\mathrm{Cu})$, Chromium (Cr), Manganese (Mn), Lead (Pb), Nickel (Ni) and Zinc ( $\mathrm{Zn})$ in lake bed sediments were analyzed using comparative sediment quality guidelines from various derived criteria. The results were also subjected to the Geo-accumulation and Pollution Load Indices. The purpose of this entire experiment was to establish an overall deterioration trend in these fragile wetlands and help mobilize appropriate ways in the current conservation efforts to save the vanishing urban aquatic ecosystems.

\section{MATERIALS AND METHODS}

About the Study Area: Bangalore (Fig. 1 and 2) is located at a Lat. of $12^{\circ} 59^{\prime} \mathrm{N}$ and Long $77^{\circ} 55^{\prime} \mathrm{E}$ at an altitude of $920 \mathrm{~m}$ above mean sea level and city's area is about $741 \mathrm{~km}^{2[11]}$. The population of Bangalore City is estimated at 5,868,448 under a greater Bangalore area of $741 \mathrm{~km}^{2}$. Given this scenario, it is not hard to imagine the sheer quantity of unaccounted sewage that ends up in the fragile wetlands of the city causing chemical pollution as well as public discomfort.

The department of economics and statistics, Government of Karnataka indicates that 95,232 ha of the land in Bangalore Urban District has been converted to non-agricultural use while 4,885 ha remain as barren land. This accounts to 100,117 ha of the total geographical area of 217,410 ha or $46 \%$ of the total geographical area of the district. In addition, approximately 1,600 acres of land in Bangalore City between Bangalore Municipal Authority (BBMP) and Bangalore Development Authority (BDA) zones are under industrial sites. These sites sometimes are closely located to lakes under this study such as Bellandur, Kengeri, Arekere, Agara, Hebbal, Byramangala, Karihobanhalli, Hebbal and their cascading drainage channels and which may be directly or indirectly responsible for the release or seepage of their hazardous effluents into these exhausted basins.

Selection of sampling areas and sampling stations: In carrying out the present study, a total of 17 lake systems located in three major watershed zones of Bangalore-Vrishabavarthy, Koramangla-Challagatta and Hebbal Valley systems with 5 of its total 6 lake series within these valley systems were selected for sampling (Table 1, Fig. 1 and 2).

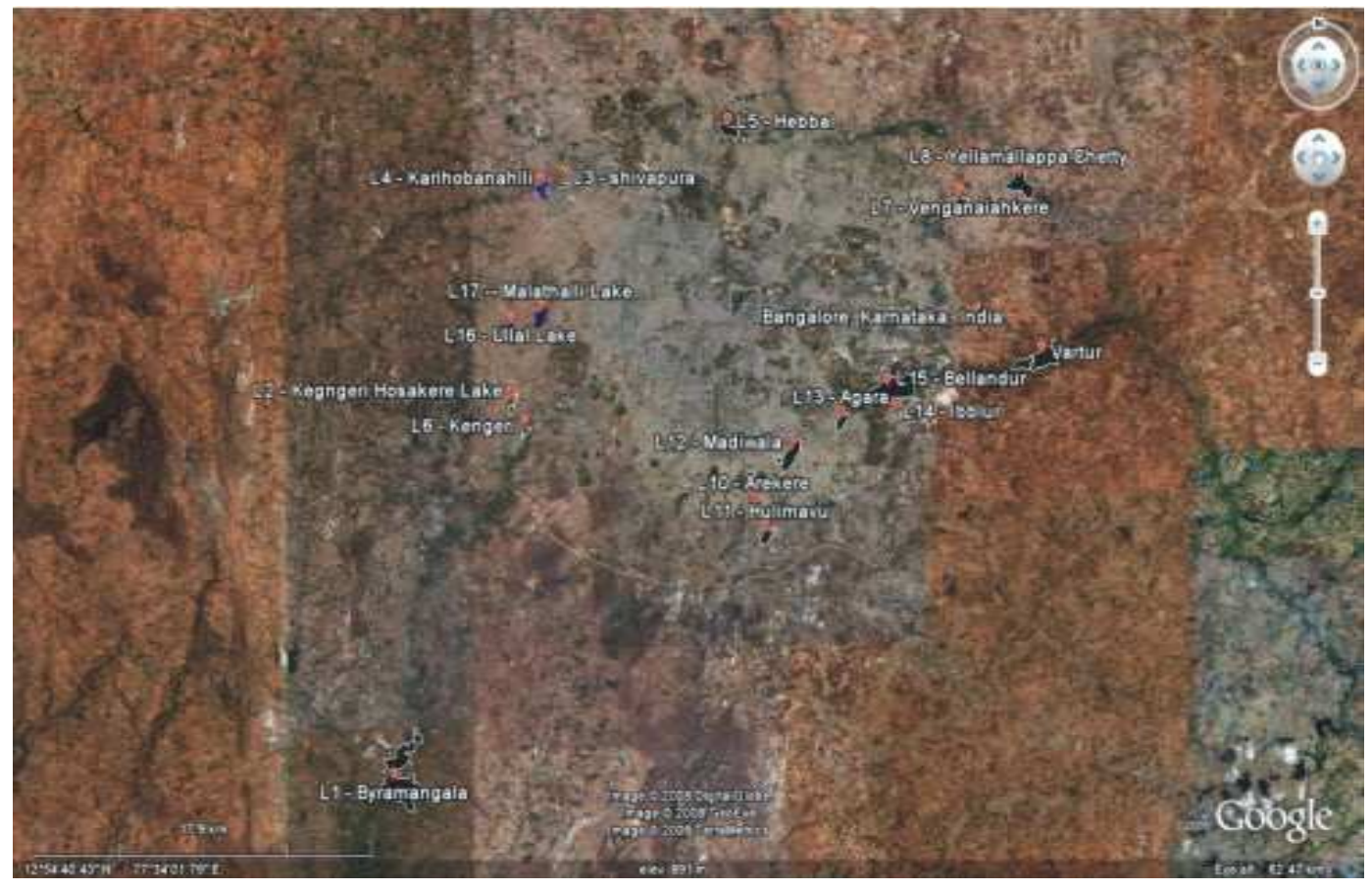

Fig. 1: A Google Earth imagery of Bangalore showing selected lakes in the study area 


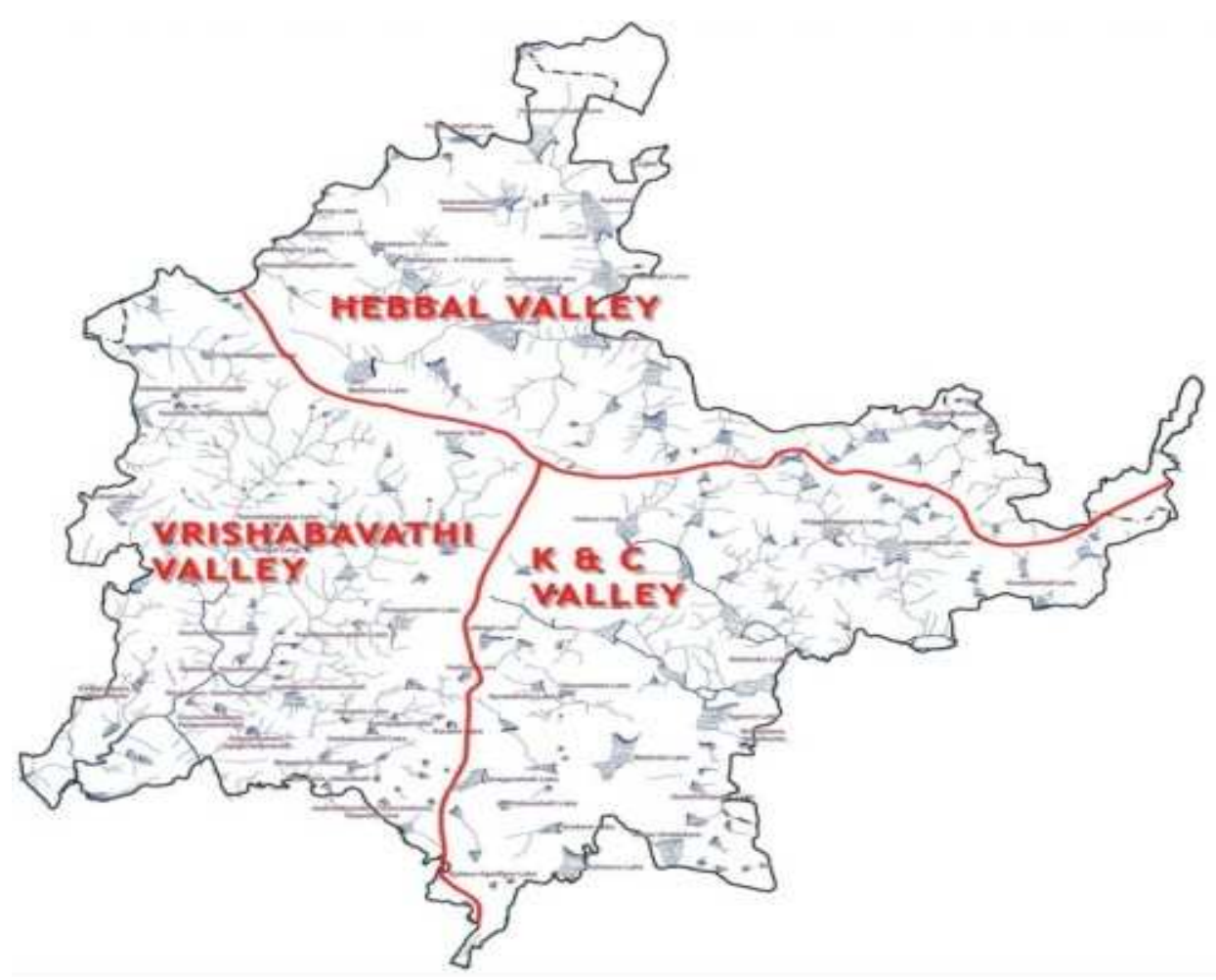

Fig. 2: A map showing the main watershed regions of Bangalore

Table 1: Sampling locations, position and sampling Points

\begin{tabular}{|c|c|c|c|c|c|c|}
\hline \multirow[b]{2}{*}{ Sr. No. } & \multirow{2}{*}{$\begin{array}{l}\text { Sampling location } \\
\text { (Name of the lake) }\end{array}$} & \multicolumn{5}{|l|}{ Position } \\
\hline & & Lat & Long & Area (ha) & Lake series & Basin \\
\hline$\overline{\mathrm{LI}}$ & Byramangala & $12^{\circ} 46^{\prime} 02.5^{\prime \prime} \mathrm{N}$ & $77^{\circ} 25^{\prime} 36.0^{\prime \prime} \mathrm{E}$ & 246.64 & Byramangala & Vrishabavathi \\
\hline L2 & Hosakere & $12^{\circ} 55^{\prime} 41.45^{\prime \prime} \mathrm{N}$ & $77^{\circ} 28^{\prime} 56.58^{\prime \prime} \mathrm{E}$ & 17.20 & Byramangala & Vrishabavathi \\
\hline L3 & Shivapura & $13^{\circ} 01^{\prime} 23.82^{\prime \prime} \mathrm{N}$ & 77³0’24.04’'E & 11.39 & Madavara & Vrishabavathi \\
\hline $\mathrm{L} 4$ & Karihobanahalli & $13^{\circ} 01 ' 14.93 ” \mathrm{~N}$ & 77²9'50.77’'E & 22.32 & Madavara & Vrishabavathi \\
\hline L5 & Hebbal & $13^{\circ} 02^{\prime} 49.17^{\prime \prime} \mathrm{N}$ & $77^{\circ} 35^{\prime} 12.48^{\prime \prime} \mathrm{E}$ & 58.23 & Yellamallappa & Hebbal \\
\hline L6 & Kengeri & $13^{\circ} 54^{\prime} 56.60^{\prime \prime} \mathrm{N}$ & 77²9'14.17'”E & 10.73 & Byramangala & Vrishabavathi \\
\hline L7 & Venganaiahkere & $13^{\circ} 01^{\prime} 00.97^{\prime \prime} \mathrm{N}$ & $77^{\circ} 41^{\prime} 56.28^{\prime \prime} \mathrm{E}$ & 18.87 & Yellamallappa & Hebbal \\
\hline L8 & Yellamallappa & $13^{\circ} 01^{\prime} 39.39^{\prime \prime} \mathrm{N}$ & 7743'67.63”'E & 37.56 & Yellamallappa & Hebbal \\
\hline L9 & Vartur & $12^{\circ} 56^{\prime} 49.50^{\prime \prime} \mathrm{N}$ & $77^{\circ} 44^{\prime} 10.54^{\prime \prime} \mathrm{E}$ & 165.75 & Vartur & Koramangala Challaghatta \\
\hline L10 & Arekere & $12^{\circ} 52^{\prime} 58.50^{\prime \prime} \mathrm{N}$ & $77^{\circ} 35^{\prime} 55.86^{\prime \prime} \mathrm{E}$ & 12.43 & Hulimavu & Koramangala Challaghatta \\
\hline L11 & Hulimavu & $12^{\circ} 52^{\prime} 14.06^{\prime \prime} \mathrm{N}$ & 77³6’20.48’'E & 23.00 & Hulimavu & Koramangala Challaghatta \\
\hline L12 & Madiwala & $12^{\circ} 54^{\prime} 22.07^{\prime \prime} \mathrm{N}$ & $77^{\circ} 37^{\prime} 06.82^{\prime \prime} \mathrm{E}$ & 91.87 & Puttenahalli & Koramangala Challaghatta \\
\hline L13 & Agara & $12^{\circ} 55^{\prime} 10.84^{\prime \prime} \mathrm{N}$ & 77³8'27.33’'E & 41.08 & Puttenahalli & Koramangala Challaghatta \\
\hline L14 & Ibblur & $12^{\circ} 55^{\prime} 19.50^{\prime \prime} \mathrm{N}$ & $77^{\circ} 40^{\prime} 00.45^{\prime \prime} \mathrm{E}$ & 8.24 & Vartur & Koramangala Challaghatta \\
\hline L15 & Bellandur & $12^{\circ} 56^{\prime} 17.62^{\prime \prime} \mathrm{N}$ & 7740’00.78’'E & 335.09 & Vartur & Koramangala Challaghatta \\
\hline L16 & Ullal & $12^{\circ} 57^{\prime} 40.70^{\prime \prime} \mathrm{N}$ & $77^{\circ} 28^{\prime} 53.24^{\prime \prime} \mathrm{E}$ & 11.03 & Byramangala & Vrishabavathi \\
\hline L17 & Malathalli & $12^{\circ} 57^{\prime} 54.78^{\prime \prime} \mathrm{N}$ & 77²9’42.29’'E & 50.38 & Byramangala & Vrishabavathi \\
\hline
\end{tabular}

The selected lakes are located around the Peri-urban rim of Bangalore-an area between the City's Corporation Limits (known as BBMP Area) and the Bangalore Development Authority (BDA) boundary and out towards the rural districts which are now being merged into a Greater Bangalore area. About 64 sampling points were selected in this study. The criterion of selection of sampling points was based upon inflow and outflow regions of the lakes; geographical proximity of industrial units in relation to their effluent discharges; proximity of residential sites located on the banks of the wetland systems; drainage patterns and accessibility towards the lakes.

Sampling of sediments for heavy metals analysis: Samples were taken from along the banks of the 
sampling station. All samples were taken from the top $10 \mathrm{~cm}$ layer to a depth of over $30 \mathrm{~cm}^{[12]}$. Sampling tools were washed and dried with water before the next sample was collected. The collected samples were stored in polythene plastic containers. Samples were air dried in the laboratory at room temperature, ground in fine mixture using mortar and pestle before sieved under $2 \mathrm{~mm}$ mesh. The samples were then stored in a polythene container ready for digestion and analysis $^{[13-16]}$.

Microwave digestion of sediments for heavy metals analysis: The accurate measurement of trace metal concentrations is an important goal in environmental monitoring and research, as many of these elements have been identified as potentially hazardous pollutants $^{[17]}$. The use of closed vessel microwaveassisted digestion systems under high temperature and pressure for acid digestion has now become routine ${ }^{[18,19]}$ as it allows shorter digestion times and good recoveries, even for volatile elements. In addition, it reduces the risk of external contamination and requires smaller quantities of acids, thus improving detection limits and the overall accuracy of the analytical method ${ }^{[20,21]}$. Moreover, they are safer and simpler and provide more controlled and reproducible conditions than hot plate or block digesters ${ }^{[20,21]}$.

For digestion of sediment samples, the samples were first dried in a room temperature. The dried samples were then ground into fine powder, sieved with $<2 \mathrm{~mm}$ sieve and stored in a plastic bag. Afterwards, about $0.25 \mathrm{~g}$ of the sample was then added into the reference vessel. Then $2.5 \mathrm{~mL}$ of conc. $\mathrm{HNO}_{3}$ and $2.5 \mathrm{~mL}$ of $\mathrm{HF}$ acid were added reaction vessel which was then inserted into a carousel and into the microwave unit ready for digestion. The system was then pre-programmed using the Ethos D control terminal (equipped with software) for $6 \mathrm{~min}$ of microwave digestion at $300 \mathrm{~W}$ power and then another 5 min of microwave digestion at $500 \mathrm{~W}$ power-then left for automatic ventilation after the digestion process for $10 \mathrm{~min}$. Afterwards, the digested solution was cooled and filtered using Whatman filter paper No. 40. The filtered sample was then made up to $100 \mathrm{~mL}$ with metal-free distilled water and stored in a special container ready for analysis.

Sample analysis for heavy metals: A Shimadzu type Atomic Absorption Spectrophotometer (AAS) 6300 model with Air- $\mathrm{C}_{2} \mathrm{H}_{2}$ flame type of an average fuel flow rate of between $0.8-4.0 \mathrm{~L} \mathrm{~min} \mathrm{~m}^{-1}$ and the support gas flow rate between 13.5-17.5 $\mathrm{L} \mathrm{min}^{-1}$ was used for sample analysis and operated as per the equipment manual. The single element hollow cathode lamps for respective metals were of Hamamatsu Photonics Co. Ltd-L2433 series. The atomic absorption analysis standards for the given elements were purchased from Inorganic Ventures Inc. and Sisco Research Laboratories Ltd. Calibration curves for various elements obtained from these standards were of first order reaction. The sample for $\mathrm{Cd}, \mathrm{Co}, \mathrm{Cu}, \mathrm{Cr}, \mathrm{Mn}, \mathrm{Ni}$, $\mathrm{Pb}$ and $\mathrm{Zn}$ analysis was aspirated with the help of an Automatic Sampler for Atomic Absorption Spectrophotometer measurement respectively. Series of reference standards-1, 2 and 3 ppm-for these metals were prepared from the purchased stock solution. The standards were prepared by pipetting $0.1,0.2$ and $0.3 \mathrm{~mL}$ respectively of the metal reference standards and made up to $100 \mathrm{~mL}$ and mounted on the automatic sampler for standard calibration curve measurement. Percentage recoveries $(\%)$ rates between metals ranged 94.8-102.3\%. The samples were finally injected into the Flame AAS and the reading was directly measured by a computer in ppm.

Interpretation of data: The results were compared with a series of universal guidelines on sediment toxicity limits by different international environmental authorities ${ }^{[17,22]}$. The sediment guidelines authorities that have been referred to herewith and of vital interest in this study are: The Screening Levels Guidelines (SLG) of Ontario Ministry of Environment (Canada) showing low and severe toxic levels for benthic and aquatic biota; the Sediment Quality Guidelines of the National Oceanographic and Atmospheric Administration (NOAA) of the United States which show the Effect Range-Low (ERL) and Effect Range Median (ERM) representing the percentile ranges of toxicity tolerance in bioassay tests for aquatic and benthic biota; the Threshold Effect Level (TEL) and the Probable Effect Level (PEL) of the Florida State Department of Environmental Protection (PDEP) in the United States; the Interim Canadian Sediment Quality Guidelines of the Canadian Council of Ministries of Environment (CCME) showing the interim sediment quality goals (IG) and the Probable Effect Level (PEL) and the Sediment Quality Objectives of the Government of Netherlands with Target Values (TV) and the Maximum Permissible Concentration (MPC) ${ }^{[22]}$. The Critical Soil Concentration range in soil is also presented on the table of results for comparison ${ }^{[23]}$.

Application of SPSS 12.0 software package for analytical evaluation of the results followed standard statistical methods ${ }^{[24]}$. This included determination of the correlation coefficient measuring the strength of linear relationship between the heavy metals in sediments in the two main seasons. Also, a One-Way 
ANOVA technique in assessing the sample means between and within specified groups. In the case of this study, the priority was on the significant relationship in group means between the spatial and temporal assessment of various parameters ${ }^{[5]}$. The results are displayed in line with accepting or rejecting the Null Hypothesis and with degrees of Freedom (dF), F-Value and the corresponding p-value respectively. In this case, a test of significance was focused upon the effects of variation between sampling locations (spatial variation) and sampling period (temporal variation) for each analyzed variable.

\section{RESULTS}

The results of the sediment quality analysis of heavy metals and their comparative assessment with different international sediment quality guidelines are tabulated in Table 2. The results for Sediment GeoAcumulation Index (GeoI) are presented on Table 3. On the part of sediment's metal contamination factor and the resulting metal Pollution Load Index (PLI) in sediment deposits in different sampling stations, the results are presented on Table 4. The results for Pearson's Correlation Coefficient are displayed on Table 5.

Cd ranged 4.68-14.25 ppm. The mean was 8.38 ppm. Comparative analysis showed that the $\mathrm{Cd}$ mean in the study area failed FDEP and CCME sediment quality goals. Moreover, $\mathrm{Cd}$ showed moderately high positive correlation with $\mathrm{Cu}$ and $\mathrm{Pb}$. In fact there was a statistical significance (moderately high positive correlation) with Co (0.05 level). No correlation was found with $\mathrm{Cr}, \mathrm{Mn}, \mathrm{Ni}$ and $\mathrm{Zn}$. One way ANOVA analysis on $\mathrm{Cd}$ between and within groups showed that there was no significant difference between and within sampling stations, $\mathrm{F}(16,44)=1.579, \mathrm{p}<0.001$.

During the Dry Season 2007-Cobalt (Co) ranged 19.61-82.30 ppm. The mean value was $47.7 \mathrm{ppm}$. The generally acceptable range of 4-20 ppm is reported for sediments ${ }^{[27]}$. But there is little literature on sediment quality guideline for $\mathrm{Co}$ but the critical range has been suggested to be between $25-50 \mathrm{ppm}$ for soil ${ }^{[23]}$. There was generally no positive correlation with many other metal species. ANOVA analysis on Co between and within groups during both dry and wet seasons showed that there was no significant difference between and within sampling stations, $\quad F(16,44)=0.720, \quad p>0.001$ and at $\mathrm{F}(16,44)=0.842, \mathrm{p}>0.001$ respectively.

The results showed that $\mathrm{Cr}$ in lake sediments ranged 10.6-320 ppm. The mean was $96.7 \mathrm{ppm}$. On comparison it was found that the $\mathrm{Cr}$ mean level in lake sediments failed only the CCME (Canada) sediment quality guidelines ${ }^{[22]}$. There was an excellent and very high positive relationship with $\mathrm{Mn}, \mathrm{Ni}$ and $\mathrm{Zn}$ at 0.01 Level. Seasonally, during the Dry Season, a statistically significant correlation with $\mathrm{Fe}$ and $\mathrm{Zn}$ was noted at 0.01 Level while another statistically significant relationship with $\mathrm{Fe}, \mathrm{Mn}, \mathrm{Ni}$ and $\mathrm{Zn}$ was noted during the Wet Season. ANOVA analysis on $\mathrm{Cr}$ in sediments between and within groups during both seasons showed that there was marked significant difference between and within sampling stations, $\mathrm{F}(16,44)=4.433, \mathrm{p}<0.001$ and $\mathrm{F}(16,44)=6.687$, $\mathrm{p}<0.001$ respectively.

Concentration in $\mathrm{Cu}$ ranged 74.9-882.2 ppm. The mean value was $203.5 \mathrm{ppm}$. This average was above all the compared sediment quality guideline authority except for the NOAA. The average was also above the soil critical concentrations. There was also an excellent and very high positive relationship with $\mathrm{Pb}$ at $<0.01$ Level while low positive correlation with $\mathrm{Pb}$ and $\mathrm{Zn}$ was noted. A moderately high positive correlation with Mn was identified. Seasonally, during the dry season, a statistically significant correlation with $\mathrm{Pb}$ and $\mathrm{Zn}$ was noted at $<0.01$ Level while another statistically significant relationship with $\mathrm{Ni}$ at $<0.05$ was identified during the Monsoon Season. There was no clear significant difference between and within sampling stations in the dry season, $\mathrm{F}(16,44)=0.977$, $\mathrm{p}>0.001$. But this was opposite during the wet season when there was clear significant difference between and within sampling stations, $\mathrm{F}(16,44)=11.720, \mathrm{p}<0.001$.

Table 2: Concentrations of heavy metals ( $\mathrm{ppm}$ ) in the bed sediments of Bangalore Urban lakes

\begin{tabular}{|c|c|c|c|c|c|c|c|c|c|c|c|c|c|}
\hline \multirow[b]{2}{*}{ Metal } & \multirow{2}{*}{$\begin{array}{l}\text { Mean } \\
(\mathrm{ppm})\end{array}$} & \multirow{2}{*}{$\begin{array}{l}\text { Range } \\
(\mathrm{ppm})\end{array}$} & \multicolumn{2}{|c|}{$\begin{array}{l}\text { Screening level } \\
\text { guidelines of } \\
\text { Ontario ministry } \\
\text { of environment }^{[22]}\end{array}$} & \multicolumn{2}{|c|}{$\begin{array}{l}\text { NOAA sediment } \\
\text { quality guidelines }^{[22]}\end{array}$} & \multicolumn{2}{|c|}{$\begin{array}{l}\text { FDEP sediment } \\
\text { quality guidelines }\end{array}$} & \multicolumn{2}{|c|}{$\begin{array}{l}\text { The (CCME) interim } \\
\text { sediment quality }\end{array}$} & \multicolumn{2}{|c|}{$\begin{array}{l}\text { Sediment quality } \\
\text { objectives in } \\
\text { guidelines } \\
\text { Netherlands } \\
17,22,29]\end{array}$} & \multirow{2}{*}{$\begin{array}{l}\text { Critical soil } \\
\text { concentration } \\
\text { ranges }{ }^{[23]} \\
(\mathrm{ppm})\end{array}$} \\
\hline & & & Low & Severe & ERL & ERM & TEL & PEL & IGM & PEL & $\mathrm{TV}$ & MPC & \\
\hline $\mathrm{Cd}$ & 8.38 & $4.68-14.25$ & 0.6 & 10 & 1.2 & 9.6 & 0.68 & 4.21 & 0.6 & 3.5 & 0.8 & 12 & $3-8$ \\
\hline $\mathrm{Co}$ & 47.70 & $19.61-82.30$ & - & - & - & - & - & - & - & - & - & - & $25-50$ \\
\hline $\mathrm{Cr}$ & 96.70 & $10.68-320.0$ & 26.0 & 110 & 81.0 & 370.0 & 52.30 & 160.00 & 37.3 & 90.0 & - & - & $75-100$ \\
\hline $\mathrm{Cu}$ & 203.50 & $74.90-882.2$ & 16.0 & 110 & 34.0 & 270.0 & 18.70 & 108.00 & 35.7 & 197.0 & 36.0 & 73 & $60-125$ \\
\hline $\mathrm{Mn}$ & 176.00 & $60.00-534.5$ & 460.0 & 1110 & - & - & - & - & - & - & - & - & $1500-3000$ \\
\hline $\mathrm{Ni}$ & 97.64 & $28.31-495.6$ & 16.0 & 75 & 20.9 & 51.6 & 15.90 & 42.80 & - & - & - & - & 100 \\
\hline $\mathrm{Pb}$ & 206.00 & $36.58-2266.3$ & 31.0 & 250 & 46.7 & 218.0 & 30.20 & 112.00 & 35.0 & 91.3 & 85.0 & 530 & $100-400$ \\
\hline $\mathrm{Zn}$ & 220.90 & $19.60-1118.25$ & 120.0 & 820 & 150.0 & 410.0 & 124.00 & 271.00 & 123.0 & 315.0 & 140.0 & 620 & $70-400$ \\
\hline
\end{tabular}


Am. J. Environ. Sci., 5 (6): 678-687, 2009

Table 3: Sediment Geo-Accumulation Indices (Igeo) of metals in lakes of Bangalore

\begin{tabular}{lllllllll}
\hline Lakes & $\mathrm{Cd}$ & $\mathrm{Co}$ & $\mathrm{Cr}$ & $\mathrm{Cu}$ & $\mathrm{Mn}$ & $\mathrm{Ni}$ & $\mathrm{Pb}$ & $\mathrm{Zn}$ \\
\hline Byramangala & 0.00 & 1.76 & 0.27 & 0.95 & 0.00 & 0.85 & 1.03 & 1.66 \\
Hosakere & 0.14 & 2.00 & 0.00 & 1.80 & 0.00 & 0.84 & 0.89 & 1.43 \\
Shivapura & 0.23 & 1.72 & 0.86 & 1.72 & 0.00 & 2.66 & 1.98 & 2.68 \\
Karihobanhalli & 0.58 & 1.73 & 0.38 & 3.08 & 0.00 & 1.23 & 5.02 & 1.83 \\
Hebbal & 0.84 & 1.65 & 0.00 & 1.24 & 0.00 & 0.71 & 1.83 & 2.05 \\
Kengeri & 0.46 & 2.22 & 0.00 & 1.43 & 0.00 & 0.73 & 0.90 & 1.40 \\
Venganaiahkere & 0.62 & 1.72 & 0.00 & 2.04 & 0.00 & 1.78 & 1.40 & 0.00 \\
Yellamallappa & 0.64 & 2.46 & 0.00 & 1.22 & 0.00 & 0.15 & 1.47 & 0.00 \\
Vartur & 0.50 & 1.75 & 0.00 & 1.18 & 0.00 & 0.20 & 1.13 & 0.47 \\
Arekere & 0.00 & 0.00 & 0.00 & 0.61 & 0.00 & 0.61 & 1.37 & 0.00 \\
Hulimavu & 0.06 & 1.90 & 0.00 & 1.18 & 0.00 & 0.30 & 1.29 & 0.00 \\
Madiwala & 0.36 & 1.84 & 0.00 & 1.30 & 0.00 & 0.06 & 1.94 & 0.00 \\
Agara & 0.23 & 2.07 & 0.00 & 1.55 & 0.00 & 0.38 & 1.68 & 0.00 \\
Ibblur & 0.67 & 1.83 & 0.00 & 1.18 & 0.00 & 0.00 & 1.79 & 0.00 \\
Bellandur & 0.14 & 1.02 & 0.00 & 1.16 & 0.00 & 0.00 & 2.25 & 0.00 \\
Ullal & 0.39 & 2.17 & 0.02 & 1.34 & 0.00 & 0.87 & 2.24 & 0.00 \\
Malathalli & 0.99 & 2.03 & 0.00 & 1.30 & 0.00 & 1.24 & 1.61 & 0.00 \\
\hline Note: Igeo scale & (99): $0-1$ (Least polluted) & 1-2 (moderately & polluted) & $2-3$ \\
(moderate to strongly polluted) & $3-4$ (strongly & to very & strong & pollution) & $4-5$ \\
(strong to very strong pollution) more than 5 (extreme pollution) & &
\end{tabular}

Table 4: Metal contamination factor (cf) and sediment Pollution Load Index $(\mathrm{PLI})^{[33]}$

\begin{tabular}{llllllllll}
\hline Lakes & $\mathrm{CF}_{\mathrm{Cd}}$ & $\mathrm{CF}_{\mathrm{Co}}$ & $\mathrm{CF}_{\mathrm{Cr}}$ & $\mathrm{CF}_{\mathrm{Cu}}$ & $\mathrm{CF}_{\mathrm{Mn}}$ & $\mathrm{CF}_{\mathrm{Ni}}$ & \multicolumn{1}{c}{$\mathrm{CF}_{\mathrm{Pb}}$} & $\mathrm{CF}_{\mathrm{Zn}}$ & $\mathrm{PLI}$ \\
\hline Byramangala & 1.34 & 0.82 & 1.97 & 0.53 & 0.16 & 2.25 & 0.46 & 1.28 & 0.840 \\
Hosakere & 1.74 & 1.05 & 0.92 & 1.24 & 0.10 & 2.23 & 0.40 & 1.01 & 0.811 \\
Shivapura & 1.89 & 0.79 & 3.56 & 1.15 & 0.48 & 13.81 & 1.19 & 3.55 & 1.900 \\
Karihobanhalli & 2.68 & 0.79 & 2.20 & 4.48 & 0.28 & 3.28 & 24.82 & 1.51 & 2.270 \\
Hebbal & 3.51 & 0.73 & 0.84 & 0.71 & 0.15 & 1.95 & 1.02 & 1.89 & 0.983 \\
Kengeri & 2.39 & 1.30 & 1.03 & 0.86 & 0.24 & 2.00 & 0.40 & 0.98 & 0.920 \\
Venganaiahkere & 2.79 & 0.79 & 0.24 & 1.58 & 0.08 & 5.71 & 0.67 & 0.19 & 0.682 \\
Yellamallappa & 2.85 & 1.65 & 0.46 & 0.70 & 0.08 & 1.12 & 0.71 & 0.06 & 0.530 \\
Vartur & 2.47 & 0.81 & 0.12 & 0.67 & 0.13 & 1.17 & 0.51 & 0.39 & 0.512 \\
Arekere & 0.00 & 0.00 & 0.34 & 0.38 & 0.10 & 1.77 & 0.65 & 0.08 & 0.260 \\
Hulimavu & 1.60 & 0.94 & 0.00 & 0.67 & 0.08 & 1.30 & 0.59 & 0.07 & 0.461 \\
Madiwala & 2.15 & 0.89 & 0.73 & 0.75 & 0.10 & 1.02 & 1.14 & 0.19 & 0.625 \\
Agara & 1.89 & 1.11 & 0.98 & 0.97 & 0.12 & 1.41 & 0.89 & 0.19 & 0.703 \\
Ibblur & 2.95 & 0.88 & 0.74 & 0.67 & 0.05 & 0.85 & 0.98 & 0.08 & 0.508 \\
Bellandur & 1.74 & 0.39 & 0.81 & 0.65 & 0.08 & 0.79 & 1.56 & 0.11 & 0.501 \\
Ullal & 2.23 & 1.24 & 1.52 & 0.79 & 0.25 & 2.28 & 1.55 & 0.18 & 0.926 \\
Malathalli & 4.07 & 1.08 & 0.72 & 0.76 & 0.21 & 3.31 & 0.82 & 0.14 & 0.809 \\
\hline
\end{tabular}

Table 5: Overall Pearson's correlation coefficient of Heavy Metals in \begin{tabular}{lllllllll}
\multicolumn{1}{c}{ Lake Bed Sediments } \\
\hline $\mathrm{Cd}$ & $\mathrm{Co}$ & $\mathrm{Cr}$ & $\mathrm{Cu}$ & $\mathrm{Mn}$ & $\mathrm{Ni}$ & $\mathrm{Pb}$ & $\mathrm{Zn}$
\end{tabular}

\begin{tabular}{|c|c|c|c|c|c|c|c|c|}
\hline & $\mathrm{Cd}$ & Co & $\mathrm{Cr}$ & $\mathrm{Cu}$ & $\mathrm{Mn}$ & $\mathrm{Ni}$ & $\mathrm{Pb}$ & $\mathrm{Zn}$ \\
\hline$\overline{\mathrm{Cd}}$ & 1.000 & & & & & & & \\
\hline Co & $0.507(*)$ & 1.000 & & & & & & \\
\hline $\mathrm{Cr}$ & -0.063 & 0.015 & 1.000 & & & & & \\
\hline $\mathrm{Cu}$ & 0.188 & 0.005 & 0.381 & 1.000 & & & & \\
\hline $\mathrm{Mn}$ & 0.076 & 0.089 & $0.869(* *)$ & 0.329 & 1.000 & & & \\
\hline $\mathrm{Ni}$ & 0.014 & -0.079 & $0.720(* *)$ & 0.205 & $0.791(* *)$ & 1.000 & & \\
\hline $\mathrm{Pb}$ & 0.127 & -0.082 & 0.363 & $0.949(* *)$ & 0.297 & 0.056 & 1.000 & \\
\hline $\mathrm{Zn}$ & 0.023 & -0.079 & $0.825(* *)$ & 0.289 & $0.797(* *)$ & $0.766(* *)$ & 0.225 & 1 \\
\hline
\end{tabular}

The mean value for $\mathrm{Mn}$ in the lake bed sediments were $176.0 \mathrm{ppm}$. The range was $60.0-534.5 \mathrm{ppm}$. Little literature is there on the Mn sediment toxicity limit for aquatic life but $\mathrm{Mn}$ in the study area can be considered to be under safe limit as prescribed by the Screening Level Guidelines (SLG). A strong correlation with $\mathrm{Ni}$ and $\mathrm{Zn}$ was noted at $<0.01$ Level. Meanwhile, a low positive correlation with $\mathrm{Pb}$ was also noted. Seasonally, an excellent relationship was found with $\mathrm{Ni}$ and $\mathrm{Zn}$ at $<0.01$ Level during the wet season but there was a clear significant difference between and within sampling stations during the dry season, $F(16,44)=7.156$, $\mathrm{p}<0.001$. But during the wet season, no significant difference between and within sampling stations was noted, $\mathrm{F}(16,44)=0.853, \mathrm{p}>0.001$.

The results show that $\mathrm{Ni}$ in lake bed sediment samples ranged 28.31-495.6 ppm. The mean was $97.64 \mathrm{ppm}$. The results indicate that $\mathrm{Ni}$ average in the study area was above the SLG and NOAA sediment quality guidelines and the probable effect level of 35.9 $\mathrm{ppm}^{[22]}$. A strong correlation with $\mathrm{Zn}$ was noted at $<0.01$ Level. Seasonally, an excellent relationship was found with $\mathrm{Zn}$ at $<0.01$ Level during the wet season. There was significant difference between and within sampling stations during the dry season, $\mathrm{F}(16,44)=$ $11.874, \mathrm{p}<0.001$; but not during the wet season, $\mathrm{F}(16,44)=1.528, \mathrm{p}>0.001$.

The results show that the $\mathrm{Pb}$ concentrations deposited in the lake bed sediments ranged 36.58$2266.3 \mathrm{ppm}$. The mean was $206.0 \mathrm{ppm}$. The mean was above the FDEP and CCME sediment quality guidelines ${ }^{[22]}$. $\mathrm{Pb}$ was within critical concentration range for soils ${ }^{[23]}$. There was no significant difference during the dry and wet seasons between and within sampling stations, $\mathrm{F}(16,44)=1.186, \mathrm{p}>0.001$ and $\mathrm{F}(16,44)=2.238, \mathrm{p}>0.001$, respectively.

$\mathrm{Zn}$ in the study ranged $19.6-1118.25 \mathrm{ppm}$. The mean value was $220.9 \mathrm{ppm}$. With this mean value, the average $\mathrm{Zn}$ in the lake sediments were within all stipulated guideline limits. This is also supported by the PEL limit of $315.0 \mathrm{ppm}^{[22,29,30]}$. There was no significant difference between and within sampling stations during the dry season, $\mathrm{F}(16,44)=2.455$, $\mathrm{p}>0.001$. But during the wet season the difference between and within sampling stations was $F(16,44)=$ 4.803, $\mathrm{p}<0.001$.

Sediment geo-accumulation index: Sediment Geo Accumulation Index (GeoI) is the quantitative check of metal pollution in aquatic sediments. It can be determined as:

$$
\mathrm{GeoI}=\ln [\mathrm{Can} / 1.5 * \mathrm{Bn})
$$

Where:

$\mathrm{C}=$ The concentration of the metal in the sediments

$\mathrm{Bn}=$ The background value (reference) in an uncontaminated sediment environment in water bodies $^{[9]}$

In the study area, the background or reference values for sediments in fresh water aquatic environment have been employed from previous studies ${ }^{[9]}$.These 
background values are $\mathrm{Cu}(27.0 \mathrm{ppm}), \mathrm{Ni}(23.0 \mathrm{ppm})$, $\mathrm{Pb}(10.0 \mathrm{ppm})$ and $\mathrm{Zn}(51 \mathrm{ppm})$. Background value for Co in India has been reported to be $20.0 \mathrm{ppm}^{[27]}$. Cd background value is quoted from the universally accepted PEL threshold limit of $3.5 \mathrm{ppm}^{[17,22]}$. The GeoI values show that the heavy metal species contamination in the lake bed sediments of the study area following the trend:

$$
\mathrm{Co}>\mathrm{Pb}>\mathrm{Ni}>\mathrm{Cu}>\mathrm{Zn}>\mathrm{Cd}>\mathrm{Cr}>\mathrm{Mn}
$$

Pollution load index for metals in sediments: This index is used to determine the mutual contamination effect of the studied metal species and has been derived as the Pollution Load Index (PLI) as the $n$th root of the Contamination Factor (CF) of studied metals in an aquatic ecosystem. In the equation, PLI $=\left(\mathrm{CF}_{\text {metal }}\right)^{1 / \text { nth }}$ where nth denotes the number of metal ions being investigated ${ }^{[33]}$. The value for Contamination Factor of the metal is obtained by the dividing the concentration of the individual metal species to its respective background value.

\section{DISCUSSION}

The average abundance of $\mathrm{Cd}$ in the Earth's crust is $0.16 \mathrm{ppm}$; in soils it is 0.1- 0.5 ppm. Cadmium metal is used mainly as an anticorrosive, electroplated on to steel. Cadmium sulfide and selenide are commonly used as pigments in plastics. Also used in electric batteries and in various electronic components. Along with inorganic fertilizers produced from phosphate ores which constitute a major source of diffuse cadmium pollution, these are the main sources of $\mathrm{Cd}$ effluent discharge ${ }^{[25-27,31]}$. Moreover, when ingested by humans, cadmium accumulates in the intestine, liver and kidney $^{[28]}$. The kidney cortex is regarded as the most sensitive organ. The health effects of chronic exposure of $\mathrm{Cd}$ include proximal tubular disease and osteomalacia.

The average Cobalt abundance in earth's crust is $29 \mathrm{ppm}$; in soils it is 1.0-14 ppm; Cobalt is widely used as alloy for various steels, in electroplating, in fertilizers, porcelain and glass making. Cobalt is considered essential for algae and bacteria but not essential to higher plants. In animals it is only requires in trace basis ${ }^{[25,27,28]}$.

Chromium is found chiefly in Chrome-Iron Ore $\left(\mathrm{FeO}-\mathrm{Cr}_{2} \mathrm{O}_{3}\right)$. Chromium is considered non-essential for plants, but an essential element for animals. The average abundance of $\mathrm{Cr}$ in the earth's crust is 122 $\mathrm{ppm}$; in soils $\mathrm{Cr}$ ranges from 11-22 ppm. It is used in alloys, in electroplating and in pigments. Chromium and its salts are used in the leather tanning industry, the manufacture of catalysts, pigments and paints, fungicides, the ceramic and glass industry and in photography and for chrome alloy and chromium metal production, chrome plating and corrosion control $^{[25,27,28]}$. Hexavalent compounds are carcinogenic by inhalation and are corrosive to tissue.

The average abundance of Copper is $68 \mathrm{ppm}$; in soils it is between 9 and $33 \mathrm{ppm}$. Copper is widely used in electrical wiring, roofing, various alloys, pigments, cooking utensils, piping and in the chemical industry. Copper is present in munitions, alloys (brass, bronze) and coatings. Copper compounds are used as or in fungicides, algicides, insecticides and wood preservatives and in electroplating, azo dye manufacture, engraving, lithography, petroleum refining and pyrotechnics. Copper compounds can be added to fertilizers and animal feeds as a nutrient to support plant and animal growth Copper compounds are also used as food additives ${ }^{[25,27,28]}$. In addition, copper salts are used in water supply systems to control biological growths in reservoirs and distribution pipes and it forms a number of complexes in natural waters with inorganic and organic ligands ${ }^{[28]}$. The aqueous species of Copper include $\mathrm{Cu}^{2+}, \mathrm{Cu}(\mathrm{OH})_{2}$ and $\mathrm{CuHCO}^{3+}$.

$\mathrm{Mn}$ in Earth's crust is $1060 \mathrm{ppm}$; in soils it is 61$1060 \mathrm{ppm}$. The common aqueous species found in water is predominantly $\mathrm{Mn}^{2+}$ and $\mathrm{Mn}^{4+}$. Manganese is essential for plants and animals. Manganese dioxide and other manganese compounds are used in products such as batteries, glass and fireworks. Potassium permanganate is used as an oxidant for cleaning, bleaching and disinfection purposes. Manganese greensands are used in some locations for potable water treatment. An organic manganese compound, Methylcyclopentadienyl Manganese Tricarbonyl (MMT), is used as an octane-enhancing agent in unleaded petrol in Canada, the USA, Europe, Asia and South America. Other manganese compounds are used in fertilizers, varnish and fungicides and as livestock feeding supplements. Manganese can be adsorbed onto soil, the extent of adsorption depending on the organic content and cation exchange capacity of the soil. It can bioaccumulate in lower organisms (e.g., phytoplankton, algae, molluscs and some fish) but not in higher organisms; bio-magnification in food chains is not expected to be very significant ${ }^{[25,27,28]}$.

The background value for Ni in Earth's crust is 1.2 ppm; in soils it is $2.5 \mathrm{ppm}$. The common aqueous species found in water is predominantly $\mathrm{Ni}^{2+}$. It is suspected to be essential trace elements for plants and animals. Nickel may be present in some ground waters 
as a consequence of dissolution from nickel ore-bearing rocks. Nickel is used principally in its metallic form combined with other metals and nonmetals as alloys. Nickel alloys are characterized by their hardness, strength and resistance to corrosion and heat. Nickel is also used mainly in the production of stainless steels, non-ferrous alloys and super alloys. Other uses of nickel and nickel salts are in electroplating, as catalysts, in nickel-cadmium batteries, in coins, in welding products and in certain pigments and electronic products. It is estimated that $8 \%$ of nickel is used for household appliances. Nickel is also incorporated in some food supplements, which can contain several micrograms of nickel per tablet ${ }^{[25,27,28]}$.

The average abundance is Earth's crust is $13 \mathrm{ppm}$; in natural soils background level ranges from 2.6-25 ppm; The common aqueous species are hydroxides and carbonates of $\mathrm{Pb}^{2+}$. Lead in water comes from industrial, mines and smelter discharges before being deposited in the sediment sinks. Lead is non essential for plants and animals and is toxic by ingestion-being a cumulative poison. Lead is also used in the production of lead acid batteries, solder, alloys, cable sheathing, pigments, rust inhibitors, ammunition, glazes and plastic stabilizers. Tetraethyl and tetramethyl lead are important because of their extensive use as antiknock compounds in petrol ${ }^{[25,27,28,32]}$. Lead toxicity leads to anaemia both by impairment of haemobiosynthesis and acceleration of red blood cell destruction. Both are dose related. Lead also depresses sperm count ${ }^{[31]}$. In addition, $\mathrm{Pb}$ can also produce a damaging effect on the kidney, liver, male and nervous system, blood vessels and other tissues ${ }^{[31,32]}$.

The average abundance of $\mathrm{Zn}$ in Earth's crust is 76 ppm; in soils it is 25-68 ppm, Zinc is used in a number of alloys including brass and bronze, batteries, fungicides and pigments. Zinc is an essential growth element for plants and animals but at elevated levels it is toxic to some species of aquatic life ${ }^{[25]}$. In addition, $\mathrm{Zn}$ is involved in a variety of enzyme systems which contribute to energy metabolism, transcription and translation. Zinc is also potentially hazardous and excessive concentrations in soil lead to phytotoxicity as it is a weed killer ${ }^{[27,28,31]}$. Zinc is used in galvanizing steel and iron products. Zinc oxide, used in rubber as a white pigment, for example, is the most widely used zinc compound. Peroral zinc is occasionally used to treat zinc deficiency in humans. Zinc carbamates are used as pesticides ${ }^{[31]}$.

\section{CONCLUSION}

From the above observations, it is clear that $\mathrm{Cu}$ and $\mathrm{Ni}$ showed more pronounced levels of pollution followed by $\mathrm{Pb}$ and $\mathrm{Cd}$. Chromium failed a single sediment quality guideline while $\mathrm{Zn}, \mathrm{Mn}$ and $\mathrm{Co}$ remained within the safety levels of all sediment quality guidelines prescribed for the study. The Sediment Geoaccumulation Index showed that $\mathrm{Co}, \mathrm{Cu}$ and $\mathrm{Pb}$ levels showed moderate pollution while the Pollution Load Index (PLI) between heavy metals in the lakes produced the following outputs:

$$
\mathrm{Ni}>\mathrm{Pb}>\mathrm{Cd}>\mathrm{Cu}>\mathrm{Cr}>\mathrm{Co}>\mathrm{Zn}>\mathrm{Mn}
$$

PLI shows the magnitude and extent of the heavy metals deposition in the lake bed sediment of the study area over a long period of time. In this case, the results suggest that the lake bed sediments in Madhavara and Byramangala Series are deposited with more heavy metal accumulation than those in the Yellamallappa, Vartur, or Hulimavu series, respectively. This study therefore indicates the increasing levels of various heavy metals species in the sediment deposits of the lake beds of the urban wetlands. If this trend is allowed to continue unabated, it is mostly likely that the local food web complexes in these fragile wetlands might be at highest risk of induced heavy metals contamination.

\section{REFERENCES}

1. Chopra, A.K., C. Pathak and G. Prasad, 2009. Scenario of heavy metals contamination in agricultural soil and its management. J. Applied Nat. Sci., $\quad$ 1: 99-108. http://ansfoundation.org/aspx_file/reportAbstract.a $\mathrm{spx} ? \mathrm{v}=1 \& \mathrm{i}=1 \& \mathrm{pp}=\% 2099-108$

2. Jumbe, A.S. and N. Nandini, 2009. Heavy metals assessment of wetlands around peenya industrial area, Bangalore, India. J. Res. Environ. Life Sci., 2: $25-30$.

http://www.geocities.com/rel_sci/issues/vol2no1.html

3. Jumbe, A.S. and N. Nandini, 2009. Impact assessment of heavy metals pollution of Vartur Lake, Bangalore. J. Applied Nat. Sci., 1: 53-61. http://ansfoundation.org/aspx_file/reportAbstract.a spx?v=1\&i=1\&pp=\%2053-61

4. Phuong, P.K., C.P.N. Son, J.J. Sauvain and J. Tarradellas, 1998. Contamination by PCB's, DDT's and heavy metals in sediments of Ho Chi Minh City's canals. J. Bull. Environ. Contam. Toxcol., 60: 347-354. DOI: $10.1007 / \mathrm{s} 001289900633$

5. Sarika, P.R. and Chandramohankumar, 2008. Geochemistry of heavy metals in the surficial sediments of Mangroves of the southwest coast of India. Chem. Ecol., 24: 437-447. DOI: 10.1080/02757540802491312 
6. Abhishek, M. and V.K. Mishra, 2008. Bioaccumulation of heavy metals in crops irrigated with secondary treated sewage waste water in surrounding villages of Varanasi city. Res. Environ. Life Sci., 1: 103-108. http://rels.110mb.com/volumes/vol1 no3.htm

7. Hejabi, A.T. and S.L. Belagali, 2009. Survey of trace metal contaminants in sediments of Kabini River in the Nanjangud industrial area, Mysore District. Nat. Environ. Pollut. Tech., 8: 49-52. http://www.neptjournal.com

8. Shukla, R. and Y.K. Sharma, 2009. Heavy Metal Toxicity in Environment. In: Environmental Monitoring and Management, Trivedi, A., K. Jaiswal, B.N. Pandey and S.P. Trivedi (Eds.). Alfa Publications, ISBN-978-81-907843-8-2, pp: 137-162.

9. Lokeshwari, H. and G.T. Chandrappa, 2006. Heavy metals content in water, water hyacinth and sediments of Lalbagh tank, Bangalore Indian J. Environ. Sci. Eng., 48: 183-188. http://www.neeri.res.in/jese/jesevol4803006.pdf

10. Lokeshwari, H. and G.T. Chandrappa, 2006. Impact of heavy metal contamination of Bellandur Lake on soil and cultivated vegetation. Curr. Sci., 91: 622-627. http://www.ias.ac.in/currsci/sep102006/622.pdf

11. Sudhira, H.S., T.V. Ramachandra and B.M.H. Subrahmanya, 2007. City profileBangalore. Cities, 24: 379-390. http://eprints.iisc.ernet.in/13302/

12. Pilotte, J.O., J.W. Winchester and R.C. Glassen, 1978. Detection of heavy metal pollution in estuarine sediments. Water Air Soil Pollut., 9: 363-368. DOI: $10.1007 / \mathrm{BF} 00280685$

13. Singh, M., G. Muller and I.B. Singh, 2002. Heavy metals in freshly deposited stream sediments of rivers associated with urbanization of the Ganga plain, India., Water Air Soil Pollut., 141: 35-54. DOI: 10.1023/A:1021339917643

14. Kronfeld, J. and J. Navrot, 1975. Aspects of trace metal contamination in the coastal rivers of Israel. Water Air Soil Pollut., 4: 127-134. DOI: 10.1007/BF01794135

15. Bifano, C. and J.L. Mogollon, 1995. Metallic contaminant profiles in sediment cores from Lake Valencia, Venezuela. J. Environ. Geochem. Health, 17: 113-118. DOI: 10.1007/BF00126079

16. Jose, A.B.N., M. Crapez, J.J. McAlister and C.G. Vilela, 2005. Concentration and Bioavailability of Heavy Metals in Sediments from Niterói Harbour (Guanabara Bay/S.E. Brazil). J. Coas. Res., 21: 811-817. DOI: 10.2112/012-NIS.1
17. CCME., 1999. Canadian water quality guidelines for the protection of aquatic life. Canadian Water Quality Index 1.0. Technical Report, Canadian Environmental Quality Guidelines Winnipeg. http://www.ec.gc.ca/ceqg-

rcqe/English/Html/water_protocol-aquatic_life.cfm

18. Hassan, N.M., P.E. Rasmussen, E. DabekZlotorzynska, V. Celo and H. Chen, 2007. Analysis of environmental samples using microwaveassisted acid digestion and inductively coupled plasma mass spectrometry: Maximizing total element recoveries. Water Air Soil Pollut., 178: 323-334. DOI: 10.1007/s11270-006-9201-3

19. Frank, E.S. and E.A. Arsenault, 1996. Microwaveassisted sample preparation in analytical chemistry. Talanta, 43: 1207-1268. DOI: 10.1016/0399140(96)01882-6

20. Valeria, S., C.M.M. Smith and A. Donovan, 2003. Microwave digestion of sediment, soils and urban particulate matter for trace metal analysis. Talanta, 60: 715-723. DOI: 10.1016/S0039-9140(03)001310

21. Nadkarni, R.A., 1984. Applications of microwave oven sample dissolution in analysis. Anal. Chem., 56: 2233-2237. DOI: 10.1021/ac00276a056

22. ANZECC and ARMCAZ, 2000. Sediment quality guidelines (in) Australian and New Zealand guidelines for fresh and marine water quality. http://www.mincos.gov.au/publications/australian_ and_new_zealand_guidelines_for_fresh_and_mari ne_water_quality

23. Maiti, S.K., 2003. Handbook of Methods in Environmental Studies: Vol. 2 Air, Noise, Soil and Overburden Analysis. ABD Publishers, ISBN: 8185771588.

24. Gaur, S.S. and A.S. Gaur, 2006. Statistical Methods for Practice and Research: A Guide to Data Analysis Using the SPSS. Sage Publications, ISBN: 10: 0761935029, pp: 208.

25. Eaton, A.D. et al., 2005. Standard Methods for the Examination of Water and Waste Water. 21th Edn., American Public Health Association, Washington, ISBN: 0875530478.

26. Mielke, H.W., J.L. Adams, R.L. Chaney, P.W. Mielke Jr. and V.C. Ravikumar, 1991. The pattern of cadmium in the environment of five minnesota cities. Environ. Geochem. Health, 13: 29-34. DOI: 10.1007/BF01783493

27. Abbasi, S.A., N. Abbasi and R. Soni, 1998. Heavy Metals in the Environment. 1st Edn., Mittal Publications, ISBN: 81-7099-657-0, pp: 314. 
28. World Health Organization, 2004. Guidelines for Drinking Water Quality. 3rd Edn., World Health Organization, ISBN: 92-4-154638-7, pp: 516.

29. Pascual, B., G. Gold-Bouchot, V. Ceja-Moreno and M. del R1'o-García, 2004. Heavy metals and hydrocarbons in sediments from three lakes from san Miguel, Chiapas, Mexico. Bull. Environ. Contam. Toxicol., 73: 762-769. DOI: 10.1007/s00128-004-0491-0

30. Knight, C., J. Kaiser, G.C. Lalor, H. Robotham and J.V. Witter, 1997. Heavy metals in surface water and stream sediments in Jamaica. Environ. Geochem. Health, 19: 63-66. http://www.springerlink.com/content/h3847200141 ptx81/

31. Anglin-Brown, B., A. Armour-Brown and G.C. Lalor, 1995. Heavy metal pollution in Jamaica 1: Survey of cadmium, lead and zinc concentrations in the Kintyre and hope flat districts. Environ. Geochem. Health, 17: 51-56. DOI: 1 0.1007/BF00146708
32. Sharma, R. and S. Pervez, 2003. Enrichment and exposure of particulate lead in a traffic environment in India. Environ. Geochem. Health, 25: 297-306. DOI: 10.1023/A:1024520522083

33. El-Sammak, A., 2001. Heavy metal pollution in bottom sediment, Dubai, united Arab emirates. Bull. Environ. Contam. Toxicol., 67: 295-302. DOI: $10.1007 / \mathrm{s} 001280124$ 